\title{
The Influence of Technological Factors on Photoconverters' Electrophysical Characteristics
}

\author{
A.A. Nikonova*, O.Y. Nebesniuk, Z.A. Nikonova \\ Engineering Institute of Zaporozhe National University, Soborniy Ave., 226, 69006 Zaporozhe, Ukraine
}

(Received 30 March 2020; revised manuscript received 15 October 2020; published online 25 October 2020)

\begin{abstract}
Solar energy represents a sensible alternative to the use of thermal, chemical and nuclear power sources. Solar radiation can satisfy the growing needs of humanity with its energetic resources. Nowadays the actual problem is the development and production of highly effective and economical photoconverters (PCs). Thus, we need new technologies and materials. Due to their high efficiency, temperature stability, and low sensitivity to radiation exposure, heterostructure-based PCs are the most promising for the use. In the article, the technology of PC production on the base of silicon structures with ITO $/ n-\mathrm{Si} / n^{+}-\mathrm{Si}$ heterojunctions is proposed. Preparation of these layers by spraying method on the surface of silicon plates is based on the results of the determination of the optimal values of heating temperature, deposition rate, velocity of gas flow from the spray nozzle, ITO layer thickness, concentration of $\mathrm{InCl}_{3}$ to $\mathrm{SnCl}_{4}$ in alcohol solution, and other factors. The technological peculiarities of producing these layers by spraying method and their influence on PC electrophysical characteristics, operational reliability and efficiency are revealed.
\end{abstract}

Keywords: Technology, Porous anti-reflective layers, Photoelectric converters, Silicon structures, Heterojunctions, Parameters characteristics.

DOI: 10.21272/jnep.12(5).05012

PACS numbers: 85.30. $-\mathrm{z}, 72.40 .+\mathrm{w}$

\section{INTRODUCTION}

Economic recovery by developing modern business requires greater growing of energetic resources which, according to scientific investigations, decrease quickly. In many countries, short- and long-term programs are taken to solve energetic problems. It is known that nuclear power contributes to the provision of our country with resources, although it requires precautionary measures. For the last years, the coal mining which is unsafe and connected with environmental pollution has reduced. Natural gas resources are enough nowadays, however their transportation and delivery are very expensive. That is why the use of alternative energy sources as the sun and the wind is given great attention and is developing successfully in our region.

The most development photoelectric industry has got in Europe, where $68 \%$ of world power is concentrated. The leader in the region is Germany where $33 \%$ of world power is set, then Italy, Spain and France. Among non-European countries in 2019 in China, the USA and Japan the powers of solar energy with 7-10 GW were located. For the last years, the quick development of solar energy takes place in China, where the total power of photoelectric stations has grown by 10 times for two years - from 0.8 GW in 2017 to $8.3 \mathrm{GW}$ in 2019 . According to Renewable Energy Policy Network for the 21st Century (REN21), in 2018 the world powers in solar thermal energy represented $255 \mathrm{GW}$ of thermal power (the most part is located in China). The stations aimed at heating water and air are essential in the structure of powers.

Semiconductor photoconverters (PCs) allow to convert solar energy into electricity with the help of homoor heterojunctions. About $91 \%$ of falling luminous flux energy is converted into electrical current because of charge carrier release out of semiconductor's volume. The base of their quality raise is getting highly effec- tive silicon nanostructures, the use of which will significantly increase the PC efficiency.

In comparison with other energy sources, PCs have great benefits:

- There are no pollutant emissions into the environment while working;

- Fossil fuel saving.

- Absence of moving elements, high serviceability gives 20 and more years of lifetime;

- Low running costs;

- Module principle of the system (to raise the plant's power it is enough to increase the number of panels) according to real needs of users.

However, it is necessary to note their deficiencies:

- High unit price of the construction;

- Energy production is not constant due to the Earth's rotation and weather conditions;

- Necessity of PC surface cleaning from the dust.

To reduce damage of optical PCs connected with the use of partial radiation, nowadays the following methods are widely used:

- Surface structuring leads to the reduction of PC integrated reflectance;

- One- or two-layer antireflection coatings marking on the PC surface;

- Contacts' space on the front surface to reduce damage for dimming;

- Metal layer coating marking on PC back surface increases the effectiveness of long-wave radiation absorption through its multiple passing across semiconductor's volume;

- The decrease of emitter-junction diode's depth and the reduction of dopant impurity concentration at the face surface for raising PC sensitivity in spectrum's shortwave part.

The authors consider that electric energy loss can be decreased with the help of the following methods:

- The choice of optimal pace and thickness of con-

\footnotetext{
*nk_alina@ukr.net
} 
tact tires on the face surface to reduce PC resistance;

- Face surface passivation to decrease speeds of the surface recombination;

- Back surface passivation and creation of isotype junctions;

- Contact area minimization and extra alloying of stratum areas to decrease recombination losses on the metal/semiconductor interface;

- The use of heteroprocessing will raise lifetime of the minority carriers;

- The use of technologies connected with getting of anti-reflective coatings on silicon structures.

Nowadays, semiconductor heterostructures underlie the designs of modern solar batteries and PCs, transistors, sources of quantum electronics, telecommunications, microwave, power supplies for communication and lighting systems. When developing an element base based on these junctions, the main attention was paid to the formation of heteroepitaxial layers of these transitions, to improving their quality (using plates with bigger diameter), and mastering the processes of alloying heterostructures. Since in the manufacture of PCs on the base of ITO $/ n-\mathrm{Si} / n^{+}-\mathrm{Si}$ compounds technological ways and operations of silicon integrated circuits (ICs) are widely used, it will allow to provide their quick progress. It is possible to get structures with required characteristics and to improve electrophysical parameters and PC quality through the selection of heterostructure's technological parameters (material, thickness, the order of layers, etc.).

Really, IBM Company claims that Si-technology provides $200-300 \%$ speed raising of instrumental structures and ICs, and high PC quality with minimum growing of their cost. For example, transistors on the base of ITO $/ n-\mathrm{Si} / n^{+}$-Si compounds can be produced both with bipolar and BiCMOS and CMOS technologies. The most perspective area of Si instrument structures' use is telecom systems. In case of entering the telecommunication market, Si ICs with ITO layers can compete not only with BiCMOS ICs and even ICs on the base of bipolar transistor silicon structures, but also with gallium-arsenide ICs.

Efficiency factor (EF) of PCs produced for the industry is about $16 \%$, in the best samples it is $25 \%$. In the lab conditions, Sharp Company achieved PC EF of $44.4 \%$, though German scientists from the Fraunhofer Institute for Solar Energy Systems and Helmholtz Center for Materials and Energy claimed about the most effective PC production in the world, its EF is $44.7 \%$. According to material, construction and the way of production, PCs can be divided into three generations: the first-generation $\mathrm{PCs}$ on the base of organic and nonorganic materials. To improve the efficiency of solar energy transformation, PCs on the base of cascade multilayer structures are created. Nowadays, the firstgeneration PCs on the base of crystal plates are widely used. In recent years, manufacturers have managed to reduce the cost of such $\mathrm{PCs}$ production in the world market. The first-generation PC types are monocrystal silicon ( $n$-Si); polycrystal silicon ( $n$-Si); on the base of GaAs; ribbon-technologies (EFG, S-web); thin-layer silicon (Apex). The largest producers of the first-generation PCs are Chinese companies Suntech Power, IA Solar, Yingli Green Solar, Solar fun Power, Trina Solar.
The second-generation thin-layer PC production technology consists in layers' covering with vacuum method. Vacuum technology, in comparison with the technology of crystal PC production, takes less energy, and the development of solar technologies in the world on this base is also characterized with less investment. It allows to produce flexible cheap PCs with big area, though conversion efficiency of such elements is lower in comparison with the first-generation PCs. The second-generation PC types: amorphous silicon $(a-\mathrm{Si})$; micro- and monosilicon (mc-Si/nc-Si); silicon on the glass (CSG); cadmium telluride (CdTe); brass-(indium)gallium (di) selenide $(\mathrm{CI}(\mathrm{G}) \mathrm{S})$.

The idea of the third-generation PC creation was to reduce the production cost, to abandon the use of expensive and toxic materials in favor of cheap and recyclable polymers and electrolytes. The important difference is the opportunity to cover the layers with printing methods, for example, on "roll-to-roll" technology (R2R). Nowadays, the main part of projects in the field of the third-generation PCs is under investigation. The thirdgeneration PC types: dye-sensitized solar cell (DSC); organic (OPV); non-organic (CN ZSS).

The aim of the project was to develop PC production technologies on the base of monocrystal silicon with heterojunctions that were created with the help of porous conductive oxide (PCO) - ITO layer.

\section{DESCRIPTION OF THE OBJECT AND METHODS OF RESEARCH}

Since heterojunctions play the great role while creating modern electrical appliances, more new and modified methods of heterostructure synthesis appear: hydrothermal method [1, 2], sol-gel method [3], MOVPE (or MOCVD), metal-organic compounds deposition out of the gas phase [4], laser deposition [5]. In the each of these methods, the accuracy and growing speed of structure are ranged. It depends what final product is necessary, the preference is given to this or that synthesis method or its modification. Because of the high perspectives in the development of high-speed optoelectronics, all the synthesis methods are aimed at obtaining materials with certain characteristics. Nowadays, there are three main features of semiconductor heterostructures: transport [6, 7], optical [7, 8] and photocatalytic [9-11].

Since the difference of real heterojunctions from ideal ones is connected with the presence of defects on the interface and in the special charge area, the presence of electric active states on the interface of the real heterojunction leads to the following effects:

- Charged states distort zone structure, raising or lowering the top of the conduction band at the interface towards Fermi level's equilibrium;

- High-density recombination centers appear, the consequence of which are large inverse saturation currents' values.

It is set that in the most cases transfer imperfectness makes electrophysical PC characteristics worse, decreasing idle current and fill factor of the currentvoltage characteristic (CVC). To create devices with good and stable characteristics it is necessary to manage both materials' volume features and interface fea- 
tures. However, problems connected with the surface cannot be considered only as PC characteristics degradation. Probably, positive results can be expected from changing the interface features. Perhaps, at the cost of surface effects, the extra perspectives of improving real PC quality indicators appear.

Today thanks to high porosity and conductivity combination, ITO material is used as the main one in the thin-layer PC production, porous electrodes of the LCD, OLED and touchscreen, and for porous electrodes creation in semiconductor photoreceivers. ITO infrared light reflects like a metallic mirror that gives an opportunity to use it in thermal protection. It can be used for creation of conductive coatings on other materials that protect from static charges.

It is found that one of the ways of high porosity satisfaction and little resistance of the barrier forming, is the use for the formation of a wide zone degenerate semiconductor barrier, for example, $\mathrm{In}_{2} \mathrm{O}_{3}, \mathrm{SnO}_{2}, \mathrm{In}_{x} \mathrm{Sn}_{y} \mathrm{O}_{2}$ (ITO) and others. They are important elements of the photosensitive receivers. The main demands required to them are maximum porosity and conductivity with enough mechanical resistance and high adhesion to the substrates.

ITO is the mixture of indium oxide III $\left(\mathrm{In}_{2} \mathrm{O}_{3}\right)$ and tin oxide IV $\left(\mathrm{SnO}_{2}\right)$. As a rule, it is used in proportion $90 \% \mathrm{In}_{2} \mathrm{O}_{3}+10 \% \mathrm{SnO}_{2}$ by weight. Thus, it is semiconductor with $n$-type conductivity that is compared with metallic, where tin ions are donors of electrons. In thin layers of about $200 \mathrm{~nm}$ applied on the glass with $400{ }^{\circ} \mathrm{C}$, ITO demonstrates high porosity and a resistance of about $6 \mathrm{Om} / \mathrm{sq}$. As it is known, in powder, ITO is yellow-green in color, but porous and without any color being deposited (for example, on the mirror) with a thin film in the width range 1000-3000 A. In this case, ITO operates as a porous and electrically conductive layer. The analysis of ITO deposition method showed that it was possible depending on necessary substrate porosity and material. While depositing on the glass, the spraying method in high vacuum is used, but in this case, the substrate, where porous electrodes are applied, can be heated up to $400{ }^{\circ} \mathrm{C}$. ITO deposition on the glass with physical spraying method (evaporation) can be provided with the help of direct current magnetron or electron beam. Less common ITO can be included into ink using relevant polymer and solution, and it can be applied on the glass with type method, though with lower porosity and conductivity comparing with physical spraying process.

ITO deposition on the semiconductor surface with magnetron spraying method includes placing of magnetron type target in the working chamber, the main magnetic field creation, the extra alternate magnetic field creation, substrate placing from the target's spraying surface side, working chamber's evacuation, argon and oxygen supply into the chamber, negative resource supply on the target, magnetron discharge creation and target's spraying with coating a substrate, for example, porous electrically conductive coating, including coating based on ITOs. It is possible to use an additional alternating magnetic field, which is created with the help of solenoid connected to a current source controlled by a generator to increase the target mass utilization factor.

One more method is the deposition of a porous elec- trically conductive ITO coating, which includes reactive magnetron sputtering of a metal target, and the deposition in a working chamber of the coating on a semiconductor substrate in an atmosphere of a gas mixture containing an inert gas and oxygen, with ion stimulation of the coating deposition process with an ion flow. Thus, oxygen content in the gas mixture is $25-50 \%$, and ion stimulation of the coatings' deposition process is conducted with $50-100 \mathrm{eV}$ ion energy that allows to extend the range of technological parameters of porous electrically conductive coatings' getting with high optical and electrical characteristics. However, the deficiency of this method is a large degradation of electrical characteristics, given a deposit with this method of porous electrically conductive coating on the substrates from different materials. It is especially wrong with ITO film depositing on a silicon substrate. While working in the optical active material composition it will lead to the degradation of electrical physical PC characteristics and to the large decrease of their lifetime.

It is found that in this case it is necessary to use indium oxide powders with $99.9 \%$ purity for targets' production. According to the experimental results, at small values of $\mathrm{SnO}_{2}$ in $\mathrm{SnO}_{2}: \mathrm{In}_{2} \mathrm{O}_{3}$ target (from 0 to $10 \%$ ) the concentration growth of charge carriers is observed. It is explained by the fact that $\mathrm{Sn}^{4+}$ is a donor, and through the $\mathrm{In}^{3+}$ substitution, an extra electron appears that increases free charge carrier concentration. Then, in the area from 10 to $50 \% \mathrm{SnO}_{2}$ content in $\mathrm{SnO}_{2}: \mathrm{In}_{2} \mathrm{O}_{3}$ target, the monotonous decrease in charge carrier concentration is observed. Thus, it is proved that the most optimal target composition for the production of thin ITO films is: $\mathrm{SnO}_{2}-10 \%, \mathrm{In}_{2} \mathrm{O}_{3}-90 \%$.

On the whole, the main problem with the formation of such films is that as a result of evaporation the smallest projections, called growths, are formed on the erosion areas of the target surface. The large fragments are kept on the surface in the spray chamber that is caused by the abnormal electrical discharge and by the spraying because of these growths. Such fragments stick to the formed film and are the course of quality degradation. Abnormal electrical discharge will be the cause of unstable plasma discharge that is really a problem because in this case stable evaporation cannot be done. That is why while creating a conductive film on the substrate, it is necessary to remove growths that have fallen into the sprayed target because it greatly degrades productivity and PC quality. Thus, we need a target which does not make growths or abnormal electrical discharge and that is ready for stable spraying.

Besides, porous conductive coatings (PCCs) using indium oxide can be obtained by magnetron reactive sputtering of a metal alloy target. Though such method needs precise preserving oxygen partial pressure in the working gas that is why complicated devices of plasma emission control. For modern PCs and optoelectronic devices, the higher PCC characteristics are necessary, that is not provided while using fused targets. The authors consider that the way-out from this situation is the use of oxide-ceramic targets that are produced with powder metallurgy methods. It allows to control the original material, composition precisely and to abandon the control of working gas composition. To respect the stoichiometry, it is necessary to add 5-4\% off oxygen 
into the working gas. The main difficulty in producing PCC technology on the silicon structures is the need to combine two conflicting properties of solids: porosity that is inherent in dielectrics and wide-area semiconductors and conductivity inherent in materials that strongly absorb light.

In this case, conductive thin oxide films, such as $\mathrm{In}_{2} \mathrm{O}_{3}, \mathrm{SnO}_{2}$ are more preferable than metal because they are firm and have got high adhesion to the different substrates, resistance to the hostile environment, porosity in the visible parts of the spectrum and high conductivity. Thus, different methods can be used to obtain thin PCCs: the first is chemical reactions occurring on the substrate's surface, the second is vacuum evaporation and cathode sputtering, and the third is ion beams.

\section{DESCRIPTION AND ANALYSIS OF THE RESULTS}

The authors proposed a PC production technology on the base of silicon structures with ITO $/ n-\mathrm{Si} / n^{+}-\mathrm{Si}$ heterojunctions. Production of these layers by spraying method on the surface of silicon plates is based on the determination of the optimal values of heating temperature, deposition rate, velocity of gas flow from the spray nozzle, ITO layer thickness, concentration of $\mathrm{InCl}_{3}$ to $\mathrm{SnCl}_{4}$ in alcohol solution and other factors that influence electrophysical and optical characteristics of ITO. $\mathrm{In}_{2} \mathrm{O}_{3}, \mathrm{SnO}_{2}$ layers formation was made according to the following reactions:

$$
\begin{aligned}
& 2 \mathrm{InCl}_{3}+3 \mathrm{H}_{2} \mathrm{O}=\mathrm{In}_{2} \mathrm{O}_{3}+6 \mathrm{HCl} \\
& 2 \mathrm{In}_{2} \mathrm{O}_{3}+\mathrm{Si}=4 \mathrm{InO}+\mathrm{SiO}_{2} \\
& 4 \mathrm{InO}+\mathrm{O}_{2}=2 \mathrm{In}_{2} \mathrm{O}_{3} \\
& 3 \mathrm{InO}=\mathrm{T}^{\circ} \mathrm{C}=\mathrm{In}+\mathrm{In}_{2} \mathrm{O}_{3} \\
& \mathrm{SnCl}_{4}+2 \mathrm{H}_{2} \mathrm{O}=\mathrm{SnO}_{2}+4 \mathrm{HCl} \\
& \mathrm{SnO}_{2}+\mathrm{Si}=\mathrm{SnO}+\mathrm{SiO} \\
& 2 \mathrm{SnO}+\mathrm{O}_{2}=2 \mathrm{SnO}_{2} \\
& 2 \mathrm{SnO}=\mathrm{T}^{\circ} \mathrm{C}=\mathrm{Sn}+\mathrm{SnO}_{2} .
\end{aligned}
$$

It is established that factors that influence ITO layer characteristics include: a nozzle shape determining stream outflow character; the size and shape of drops; the presence (absence) of a protective screen around the working area, where layer deposition is being made and its size; pause duration between regular stream supply, connected with gas-carrier thermal capacity value and substrate temperature changes during gas stream supply period; relief character of the substrate surface, the character of temperature distribution along the substrate surface in the layer deposition process.

During the experimental research, the thickness of the barrier forming semiconductor varied within 400$1500 \AA$, and the film resistance - from 50 to $5 \cdot 10^{4} \mathrm{Om}^{2}$.

It turned out that the substrate temperature makes a great influence on the film electrophysical characteristics. It is shown in Fig. 1 by the dependence of surface resistance $R_{S}$ of ITO film with $100 \mathrm{~nm}$ thickness obtained by spraying on the substrate temperature.

The deposited films had different microstructure that was defined by these conditions. At low temperatures of $200-300{ }^{\circ} \mathrm{C}$, deposited layers were less shiny because of the developed surface relief and they dispersed radiation diffusely. At high temperatures of $500-700{ }^{\circ} \mathrm{C}$, the cloudy layers of milk color were formed. Depending on the deposition conditions, the film microstructure varied from amorphous to polycrystalline. Under optimal treatment at $400-450{ }^{\circ} \mathrm{C}$, solid, mechanically hard films with a mirror-like surface were formed.

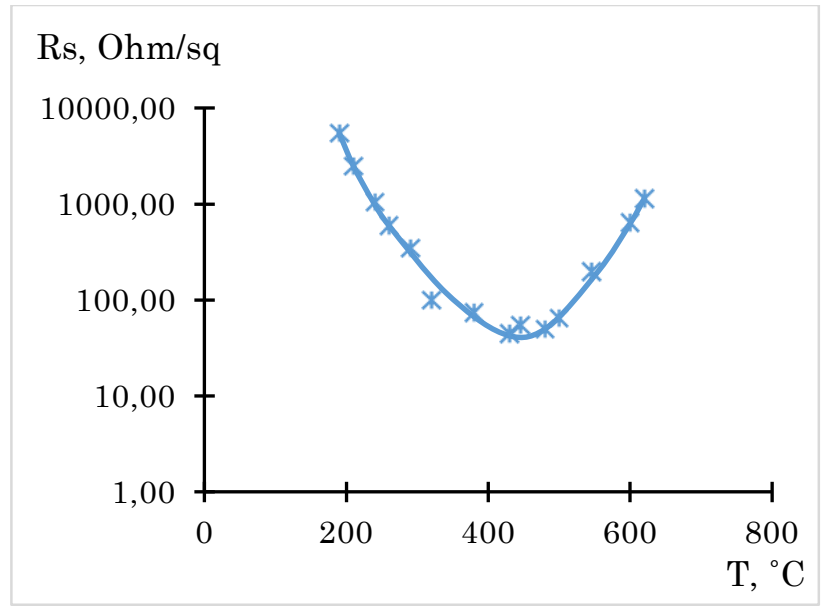

Fig. 1 - Dependence of the surface resistance on the substrate temperature

The great influence on electrophysical PC characteristics the layer ITO composition, especially $\mathrm{SnO}_{2}$ content providers. ITO layer deposition was done on the silicon epitaxial structure of $n n+$ type. The control of its parameters was held with surface electrical resistance measuring, $R_{S}$ values from layer ITO composition are represented in Fig. 2.

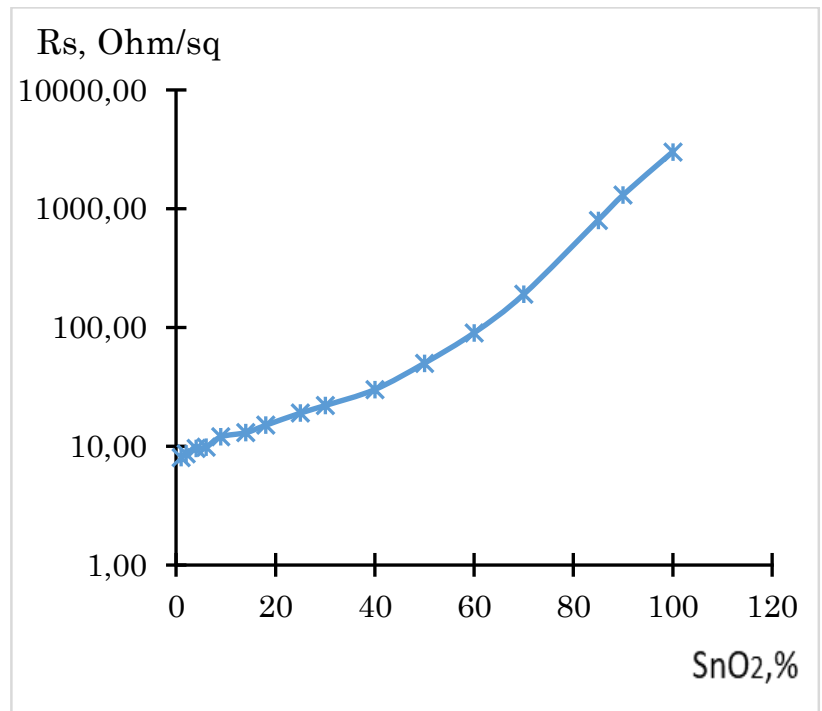

Fig. 2-Dependence of the surface resistance on the composition of the ITO layer

The analysis of these results showed that samples with a layer consisted of pure $\mathrm{In}_{2} \mathrm{O}_{3}$ without any $\mathrm{SnO}_{2}$ had the least value of electrical resistance. With increasing $\mathrm{SnO}_{2}, R_{S}$ value will grow to $1300 \mathrm{Om} / \mathrm{sq}$ for PCC layer consisted of $100 \% \mathrm{SnO}_{2}$. The authors suppose that while using the technology and these silicon structures with ITO for industrial production of PCs, it will improve considerably their efficiency. 


\section{CONCLUSIONS}

The represented concept of technology development of ITO $/ n-\mathrm{Si} / n^{+}-\mathrm{Si}$ junctions helped to identify reasons that determine the character of ITO layer conductivity depending on $\mathrm{SnO}_{2}$ content in it and their influence on the quality of $\mathrm{PCs}$ on their base. With a little $\mathrm{SnO}_{2}$ concentration in the mixture $\mathrm{In}_{2} \mathrm{O}_{3}+\mathrm{SnO}_{2}$, indium atoms are replaced with tin atoms. As a result, in the crystal lattice of indium dioxide, tin serves as a donor. With higher $\mathrm{SnO}_{2}$ concentrations, the conditions for the formation of complexes of neutral $\mathrm{SnO}_{2}$ molecules are cre- ated. It causes the reduction of conductivity. It is found that ITO layers containing about $7.7 \cdot 10^{4} \mathrm{~g} / \mathrm{mol} \mathrm{SnO}_{2}$, have the highest conductivity. The use of PCCs obtained with the help of technology developed by the authors will afford to improve PC electrophysical characteristics and their reliability in operation. The solution of these tasks will lead to the modern modelling of technological processes, improving the quality of PCs and, in case of their consumer properties maintaining, to the use of modern supplies of silicon production and semiconductor materials.

\title{
REFERENCES
}

1. Yimai Liang, Na Guo, Linlin Li, Ruiqing Li, Guijuan Ji, Shucai Gan, Appl. Surf. Sci. 332, 32 (2015).

2. Wenjun Wang, Hefeng Cheng, Baibiao Huang, Xiaolei Liu, Xiaoyan Qin, Xiaoyang Zhang, Ying Dai, J. Colloid Interface Sci. 442, 97 (2015).

3. Bilal Masood Pirzada, Niyaz A. Mir, Nida Qutub, Owais Mehraj, Suhail Sabir, M. Muneer, Mater. Sci. Eng. B 193, 137 (2015).

4. R. Loganathan, M. Jayasakthi, K. Prabakaran, R. Ramesh, P. Arivazhagan, K. Baskar, J. Alloy Compd. 616, 363 (2014).

5. Subhash Chand, Rajender Kumar, J. Alloy Compd. 613, 395 (2014).

6. B.C. Luo, J. Wang, M.M. Duan, K.X. Jin, C.L. Chen, Mater. Lett. 120, 133 (2014).

7. Upadhyay, A. Mandal, H. Ghadi, D. Pal, A. Basu, A. Agarwal, N.B.V. Subrahmanyam, P. Singh, S. Chakrabarti, J. Lumin. 161, 129 (2015).

8. Hong-Jian Feng, M. Wang, F. Liu, B. Duan, J. Tian, X. Guo, J. Alloy Compd. 628, 311 (2015).

9. Andriy V. Kozytskiy, Oleksandr Stroyuk, Mykola Skoryk, Stepan Kuchmiy, J. Photochem. Photobiol. Sci. 14, 942 (2015).

10. Xiuzhen Zheng, Danzhen Li, Xiaofang Li, Jing Chen, Changsheng Cao, Jialin Fang, Jubao Wang, Yunhui He, Yi Zheng, Appl. Catal. B: Environ. 168, 408 (2015).

11. Yanqin Wang, Xiaofang Cheng, Xiaoting Meng, Hongwu Feng, Shaogui Yang, Cheng Sun, J. Alloy Compd. 632, 445 (2015).

\section{Вплив технологічних факторів на електрофізичні характеристики фотоперетворювачів}

\author{
А.О. Ніконова, О.Ю. Небеснюк, З.А. Ніконова \\ Інженерний інститут Запорізького національного університету, пр. Соборний, 226, \\ 69006 Запоріжж, Украӥна
}

\begin{abstract}
Сонячна енергетика представляе розумну альтернативу використанню теплових, хімічних та ядерних джерел струму. За своїм енергетичним ресурсом сонячне випромінювання цілком здатне задовольнити зростаючі потреби людства. Актуальною проблемою в даний час е розробка і виготовлення високоефективних та економічних фотоперетворювачів (ФП) з достатньою радіаційною стійкістю. У зв'язку з цим потрібні нові технології і матеріали. Завдяки високій ефективності, температурній стабільності та малій чутливості до радіаційного опромінення ФП на основі гетероструктур є найбільш перспективними для використання. У статті запропонована технологія виготовлення ФП на основі кремніевих структур з гетеропереходами типу ITO $/ n-\mathrm{Si} / n^{+}-\mathrm{Si}$. Отримання цих шарів методом пульверизації на поверхні кремніевих пластин спираеться на результати визначення оптимальних значень температури нагріву, швидкості осадження і течії газового струменя з сопла пульверизатора, товщини шару ITO, концентрації $\mathrm{InCl}_{3}$ до $\mathrm{SnCl}_{4}$ в спиртовому розчині, а також інших фракторів. Виявлені технологічні особливості отримання цих шарів методом пульверизації дозволяють поліпшити електрофізичні характеристики ФП, їх надійність при експлуатації і коефіціент корисної дії.
\end{abstract}

Ключові слова: Технологія; Прозорі покриття, що просвітлюють; Фотоелектричні перетворювачі; Кремнієві структури; Гетеропереходи; Параметри; Характеристики. 